\title{
パリの中庭型共同住宅家屋の集合化要素としての共有境界壁の 形成過程に関する考察 \\ PROCESS OF FORMATION OF THE COMMON WALLS AS ELEMENT OF CONNECTION OF APARTMENT HOUSES IN PARIS
}

鈴木 隆*

Takashi SUZUKI

\begin{abstract}
We analysed the process of formation of the common walls (murs mitoyens) as element of connection of apartment houses composing the traditional urban fabric of Paris, referring to the notarial deeds, and we conclude as follows. He who acquires first a lot to build a house constructs a common wall, in such a way that either it strides a limit between adjoining houses or it does not cross that limit, and then the neighbour acquires the common ownership of the wall. In general, the former method of construction of the wall is taken when the continuity of the axes of the walls is necessary and a correspondence of the land-use of adjoining lots is assured or probable, while the latter one in contrary cases. These alternative methods reveal a positive attitude as well as a system of adjustment of interests concerning the common walls.
\end{abstract}

Keywards: Common walls (murs mitoyens), Apartment houses, Connection of houses, Lot- 1 ine, Paris, 19th century 共有(境界)壁、共同住宅家屋、家屋集合、敷地境界線、パリ、19世紀

1. はじめに

$1-1$. 問題設定

現代の一団地の開発が行われる以前に形成されたパリの伝統的な 市街地は、敷地の前面および側面の境界線に建物壁面を置いて數地 毎に建設された、中層の中庭型の内部が住戸 (appartements)に分割 された共同住宅家屋 (mai sons) の集合体として捉えられる。そうした 市街地はフランスおよびヨーロッパの他の多くの都市においても見 られ、市街地の空間構成の一つの典型をそこに見出だすことができ る。そして、それは、敷地の境界線に建物壁面を置くことを許容す る、比較的自由度の高い土地利用の結果として生み出された ${ }^{1}$ 。特 に、道路沿いに建物が連続して並び街区が一体の構築物であるかの ような市街地の景観を生み出す要因となったのは、敷地の側境界線 への建物壁面の設置であり、さらに、瞵地との境界線の上に設置さ れ双方の家屋（土地と建物を含む）の所有者が共同で所有し利用す る共有境界壁（mur mitoyen;以下、共有壁という）の存在である。 ヨーロッパの都市における共有壁の歴史は古く、古代ローマにお けるその存在も知られている ${ }^{2)}$ 。共有壁は、フランスにおいて、革 命（1789年）前のアンシャン・レジーム (旧体制) 期のパリやその 他の都市においても用いられおり、革命後の近代には民法典の中に 共有壁に関する規則が定められ、共有壁は社会的および法的に認知
されながら家屋の集合化の重要な要妻として存在し続けてきた。現 代のパリの都市計画の規則も、ほとんどの地域において、既存の都 市空間を特徽づける道路沿いの建物の連続性を維持するために、道 路から一定の距離 $(20 \mathrm{~m})$ までの敷地の部分では側境界線への建物 壁面の設圈を原則とし、共有壁をもつ中庭型家屋の都市計画上の存 続の可能性を開いている ${ }^{3)}$ 。伝統的な都市空間の存続に配慮したそ うした都市計画上の対応は、他の都市においても見られる4)。

パリの伝統的市街地を構成する中庭型家屋の成立条件の一つであ る側境界線への建物壁面の設置を究極化したところに生み出された 共有壁は、二つの家屋が壁を共有し共用することにより合理的な敖 地の利用を可能にすると同時に、個別の建築行為によってつくられ る単体の家屋を集団として把握する意思を体現する家屋の集合化の 要素として、重要な意味をもつ。共有壁の法的位圈付けに関する研 究は見られるが、共有壁の具体的な形成の過程は必ずしも明らかで

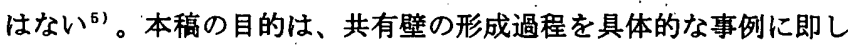
て明らかにすることによって、単体家屋の集団としての市街地の形 成過程における相隣的な土地利用調整の実態を知ることにある。

1-2. 研究の方法と対象

アンシャン・レジーム期から近代にわたるパリの市街地の歴史的 


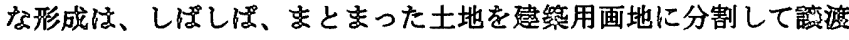
する画地分声（lotissement）によって行われてきた。そこで、共有

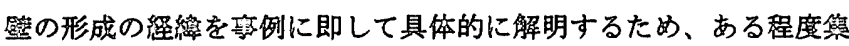

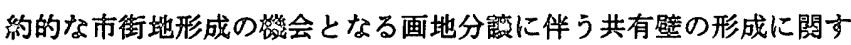
る贸寒を资湖によってつきとめ、それに分析と考综を加える。

19世紀前半のパリでは、急速な人口の堌加を背景として市街地周 辺部で多くの画地分澱が展開され、それによって生み出された地区 は今日の都心周辺の典型的な市街地となっている。その時代には既 に民法典の共有壁に闦する規則が適用されていたが、民法は一秝的

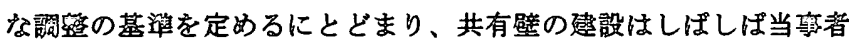
の合意による契約に従って行われた。そこで、共有壁の形成に閣す る民法の調察の仕組みを把握した上で、19世紀前半に開発されたパ リの主票な画地分筑地区の中から、敫地毎の詳細な分析を行うのに 適当な規荧であることも考虑してサン・ジョルジュ地区（図 1) を 封急として選び、画地の分諘からその後の家屋の建設までの具体的 な经過を、画地や家屋の売買に関する公正証慧原本によって辿り、 その中から共有壁の形成に関する裹実を捉えて、分析と考察を行う。 分析および引用に直接関わる公正証害原本 (フランス国立古立害館

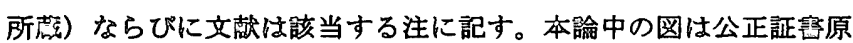
本および不的産台帳圆 (plans cadastraux)によって作成した。

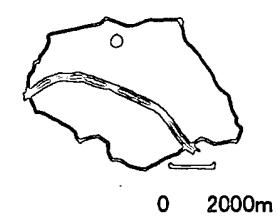

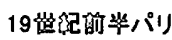

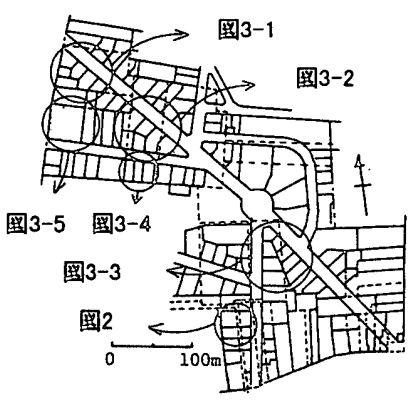

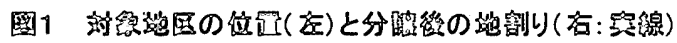

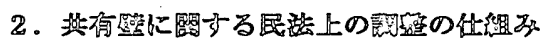

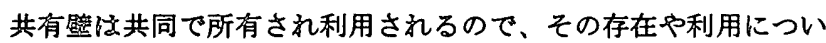
ての当旁者の間の閶係を定めることが重要な問題となる。当嘉者の 閻で取り決めがなされている場合はぞれに従って、そうではない埸 合は民法典に定められた規則に従って問題が処理される。民法典に アンシャン・レジーム期に存在していた地城の饰習法などを考展し ながら19世紀初頭に全国的に適用される規則として螎䈚され、その 後の改正を经ながら今日に継承されている。民法の規定は買習法の 的容も考留して定められたのみでなく、その規定の中にも惯行等が 存在する場合にはそれを绶先することが記されている場合があり、

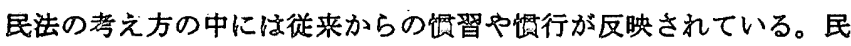
法には、共有照の諗定、瞬地の境界壁の一方的な共有化、共有譬の かさ上け゚、および共有壁の利用等に䦎する規則が定められている。

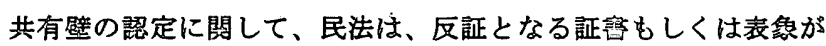
存在しない場合は、业物相互あるいは中庭や庭图相互を隔てる境界 照を共有壁とみなすという原則を定め (653条)、その限りでは境罪壁 を唋楅的に共有壁と琶める立場をとる。そして、共有の反証となる

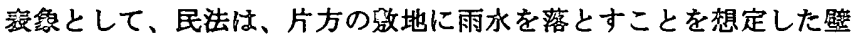
の具体的な性状（頂部の傾斜、笠石や水切り石等の装備）を揭け゚る

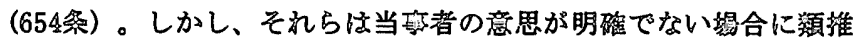

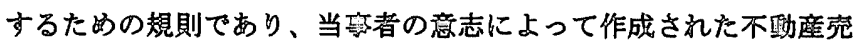

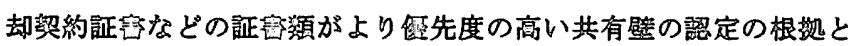

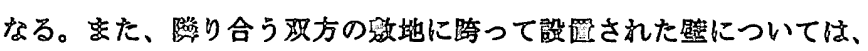

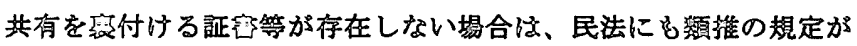
ないため、それが共有照と琶的られるか不かが实際上問題となり、

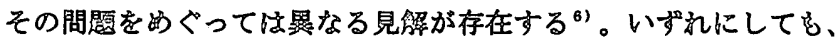

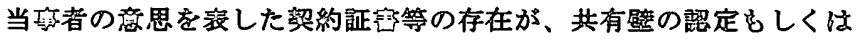
成立において雷要な器哧をるつ。

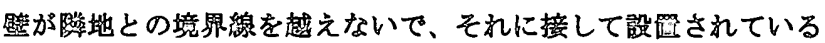

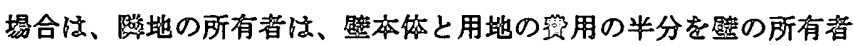
に支弘って、一方的に照の共有簿（mitoyenneté）を取得すること

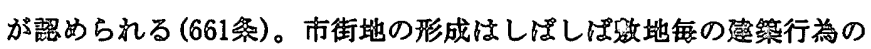

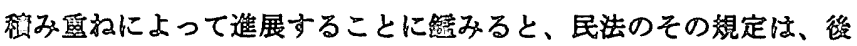

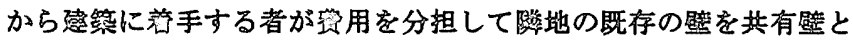
して利用するという現突的な共有譬の形成の仕組みを融めたものと いえる゙。しかし、壁の题設者の側からは、筷地の所有者に赫して 共有権の取得を強制することはできないので、そこに共有壁の形成 の仕組みとしての一整の限界があるともいえる。

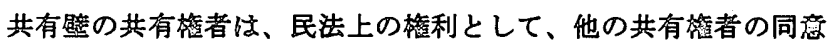
を得ることなく、一定の筑囲内で壁を利用すること（避物の支持、 梁および根太の一定限度までの埋設）が認められる(657条) ${ }^{8)}$ 。民 法仙さらに別の規定において、共有壁に工作物を支持させあるいは 埋設するためには、他方の共有権者の同意を得るか、もしくは、同 意が得られない埸合は他方の権利を侵害しないよう寄門家が定めた 必要な措圆を訜しなけれぱならないとする (662条)。後者の規定は、 前者の規定による利用以外の、共有壁の酎久性や外誽を䐎なうおそ れのある利用行為に䔔用されると解积されており、現突にしぱしぱ 行われた共有照への瞬炉队煙道の埋設等がこの規定との閣俰で問题 となる。それについて梳当旁者の合意に上る解決が求的られる。

共有譬の共有筑者は、さらに、自らの琴用で一方的に共有壁をか さ上げすること、そして壁の婎造上それが图嚾な埸合には自分の土

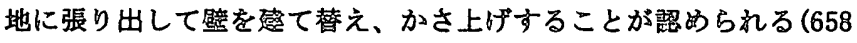
条、659条）。共有照のかさ上げは、既存の共有壁を利用して邀築あ るいは增改等などを行う埸合に必要になることがあるので、一方的

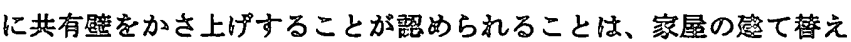
や管改筑を促進する上で雷要な意味をるつ。しかし、一方的に行わ

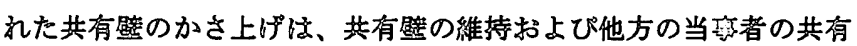
壁の利用にも影矮を与える可能传があるので、かさ上げを行う者は、 かさ上げの堅用のみでなく、かさ上げによって必要となった他方の

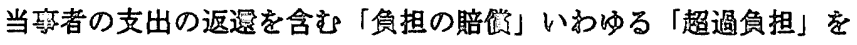

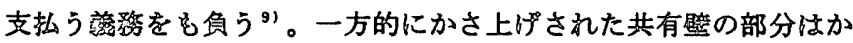
さ上げを行った者の所有になるが、他方の当琴者には、かさ上げの 劉用の半分を相手方に支払って、かさ上げされた部分を共有暨とす る権利が㒛められている。かくして、共有暨は、民法上、必ずしも 当慙者观方の合意によることなく、一方の発意によって、欢方の负 担において、形成され払大する可能性をるっている。一見して共有 の摡念と矛盾するように見えるその仕組み仙、共有壁の現実的な惢

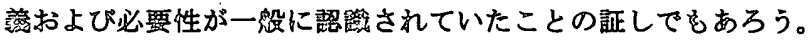




\section{3 . 共有壁の形成における画地分鿁者の仲介的役割}

画地分讓地区では、画地が売却され家屋が建設されるのに伴って、 しばしば共有壁の建設も行われた。画地の壳却および家屋の建設が 個別に展開する画地分諨にあって、共有壁の建設は必ずしも体系的 に行われたわけではないが、画地がある程度集約的に供給される画 地分鿁は共有壁の建設の機会にもなった。共有壁の建設や利用に関 する条件は、画地分讓あるいは家屋建設の当事者の合意によって定 められ、画地や家屋の売却契約書の中に記された ${ }^{10) 。 ~}$

画地分諒の展開の中でもとりわけ一団の画地が比較的限られた期 間に売却される見込みのあるような状況では、画地分譲者の主導に よって共有壁の計画的な建設が行われ易かった。共有壁の建設は、 画地の売却契約に定められた条件に従って、画地の購入者によって 行われた。その基本的な手順は、隣り合う画地の一方を最初に購入 して家屋の建設に着手する者が、まず自己の費用負担において隣地 との間の壁を建設し、後に隣地を購入する者に対して壁の費用の分 担（通常は半分）を求め、求められた側が費用を支払って壁の共有 権を取得するというものである。もつぱら画地の分謈を目的として 行動し、家屋の建設にはあまり携わらない画地分譹者は、画地購入 者による共有壁の建設の仲介的な役割を担うにとどまり、たいてい は共有壁の費用負担や費用請求の直接の当事者にはならなかった。

瞵り合う家屋が異なる主体または同じ主体によって同時期に建陪 される場合には、家屋の建設に合わせて共有壁を計画的につくりだ すことは比較的容易であろう。しかし、そうした同時的あるいは集 団的な家屋の建設は、パリの市街地の形成過程において一般的では なく、画地分变も、主として画地毎に個別に介入する個人建筑主を 対象として展開した ${ }^{11}$ 。従って、画地購入者の土地利用上の関係を 調整するために仲介する两地分譲者の行動が重要な意味をもった。

土地の境界に建設された壁については、隣地の所有者は費用の半 分を相手側に支払って壁の共有権を取得することができるが、壁の 建設者の側からは、隣地の所有者が実際にその壁を利用しているな どの状況が存在しない限り、隣地の所有者に対して壁の共有権の取 得を強制することはできない。また、いずれの側にも壁を共有壁と して建設する義務はない。従って、画地分鿁を契機として、隣接す る画地の購入者の一方が壁を建設し、他方がその共有権を取得する ことが契約によって予め定められたことは、共有壁を安定した条件 のもとで体系的につくりだす上で有効であった。

\section{4. 共有壁の二つの建設方法}

画地分譲に伴う共有壁の建設には、実際上、次の二通りの方法が 見られる。（i）最初の画地の購入者が、画地の売却契約に基づいて、 購入した画地と末売却の隣地に半分ずつかかるようにして壁を建設 し、後に隣地を購入した者が、壁本体の建設費用の半分を壁を建設 した側に支払って壁の共有権を取得する方法（方法 1)。（ii）最初 の画地の購入者が、自分の土地の上に瞵地との境界線に接して壁を 建設し、後に隣地を購入する者に対して壁（土地と本体）の共有権 の取得を要求する権利を留保し、壁を共有化する方法（方法 2）。

方法 1 によれば、建設された壁が共有壁となることが予定されて いるのみでなく、共有壁の中心線は画地の最初の境界線と重なる。 それに対して、方法 2 によれば、壁を建設した者は、契約に従って、

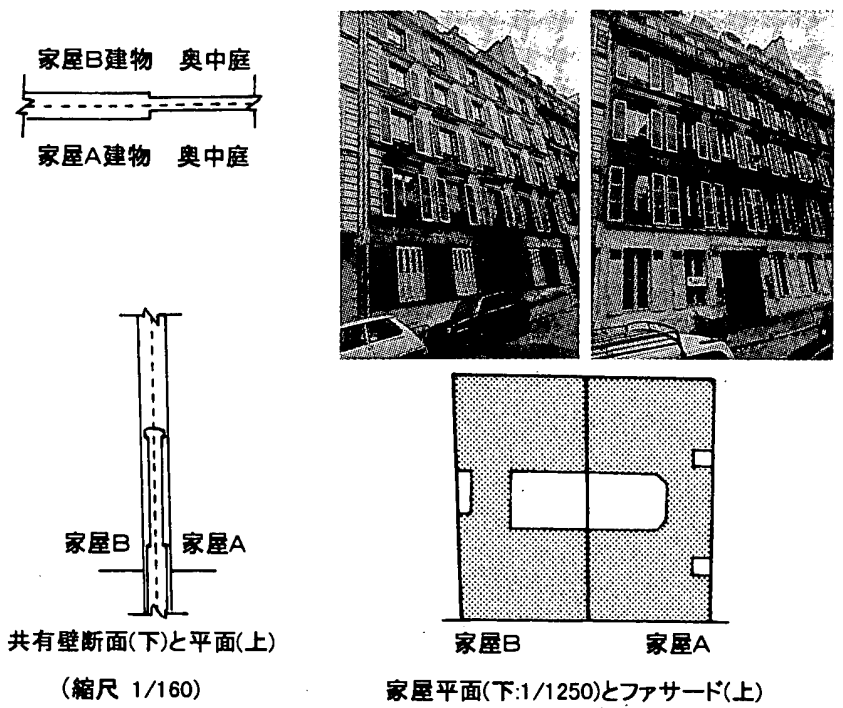

図2 厚さを異にする建物と中庭の共有壁の例

隣地の所有者に壁の共有化を求める権利を有し、瞵地の所有者は、 法律に基づいて、壁本体と用地の費用の半分を支払って壁を共有化 する権利を有するが、それらの権利が行使されなければ壁は建設し た者の専有のままとなる。また、壁が共有となれば、共有壁の中心 線が新たな土地の境界線となる。二つの共有壁の建設方法は何故に 存在し、そして現実にどのような意味をもっていたのであろうか。

\section{4ー1．境界線を跨いで建設される壁}

共有壁となる壁を契約に従って予め隣地との境界線を跨いで建設 する方法（方法 1）は、より確実に共有壁を生み出すと同時に、予 め確定された画地の境界線が共有壁の中心線になるので、計画的に 共有壁をつくりだすための有効な方法である。ところが、建物を隔 てる壁と中庭等の空地を隔てる壁は、高さのみではなく構造も異な りうる。ほほ対称な配置形熊の隣接する二つの家屋の例によれば、 建物部分の共有壁と中庭部分の共有壁の厚さにははっきりとした差 がある(およそ $49 \mathrm{~cm}$ と $27 \mathrm{~cm})^{12)}$ (図 2) 。従って、共有壁をつくるこ とについての当事者の合意の可能性に着目すると、壁の両側の土地 の利用形態に建物同士あるいは中庭等の空地同士が向かい合う対応 性があるか否かによって、合意の可能性は異なると考えられる。そ こで、実際に方法 1 によって共有壁がつくられた事例について、画 地の状況に着目して分析を行ってみると、以下の結果が得られた。

（1）該当する事例においては、隣接する画地の中庭を向かい合 わせに配置して中庭の集合体をつくる契約上の合意が存在し、画地 の利用形態の対応性が予め保証されている場合が多い13)。中庭集合 体をつくる条件をつけて売却された $4 つ の$ 画地においては、先発の 画地の購入者が、隣地との間に方法 1 によって共有壁を建設する義 務を負う (図3-1 $)^{14)}$ 。別の 3 つの中庭の集合体をもつ画地 ${ }^{15)}$ (図3$2, \mathrm{a}, \mathrm{b}, \mathrm{c}$ ) および 2 つの中庭の集合体をもつ画地 ${ }^{16)}$ (図3-2, d, e)にお いても、先に建築に着手する画地の購入者が方法 1 によって共有壁 を建設する義務を負っている。そして、中庭集合体の配置の都合上、 共有壁を挟んで建物と中庭が向かい合う場合は、壁の共有の範囲を 通常の中庭境界壁の高さである「囲壁の高さ」（後出）までとする ことによって当事者の利害の調整が図られた（図3-2, c/e間） ${ }^{17}$ 。 


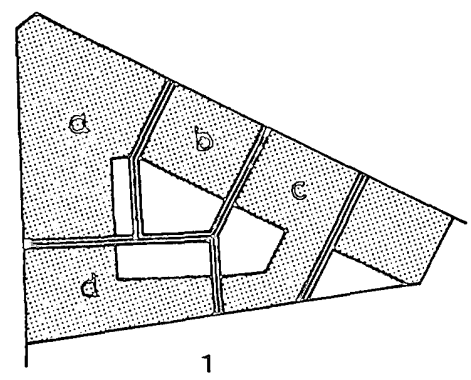

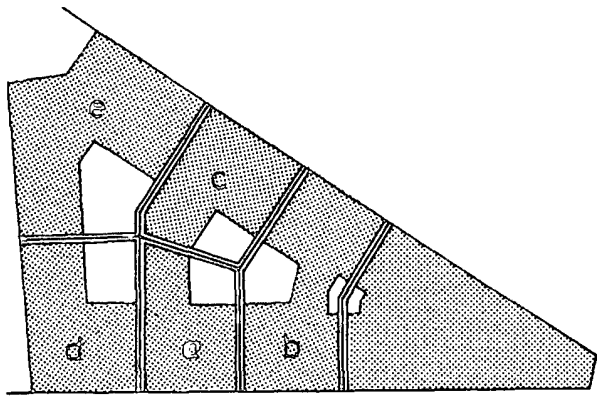

2

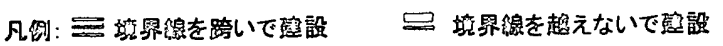

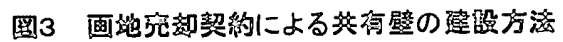

それらの㾁例において注目すべきもう一つの点は、2つの画地を 隔てる境界湶の延長上に別の境界線が連続して存在することである。 共有璧が一列に連なる場合には、壁の中心線を揃えてその連続性を 確保することが構造上も望ましいと考えられる。画地を隔てる境界 湶の延镹上に別の境界線が存在する状況では、一貫して境界線を跨 いで壁を建設することが、画地単位でつくられる共有壁の中心缐の

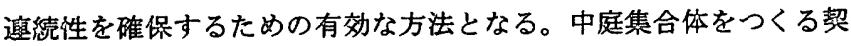
約合意によって壁の両側の画地の利用形態の対応性が予め保証され ていることが、共有壁の形成を前提としたそのような壁の建設方法 を、当豪者に受け容れられ易くしたと考えられる。

（2）中庭篹合倅をつくる契約合意が存在しないが、方法 1 によ って共有壁が垦設されている例もある。鋭角に交差する二本の道路 のいずれかに間口をもつ画地の背割り線が運続して一直線を成す状 況において、背割り湶上の共有壁が、方法 1 により、予め双方の画 地に跨って建設されている ${ }^{18)}($ 図3-3,b-h）。それは、一直線を成 す背揢り缐を基染として、中心線が一致した共有壁をつくりだすた めの措羁と考えられる。共有壁の両側の画地の利用形態を対応させ るための繁前の調整は行われていないが、共有壁の建設を当亭者に 受け容れられ易くしたと考えられる次のような条件が見出だされる。

(i) 比檠的舆行きの大きいそれらの画地の奥の部分は、中庭型家 屋の一般的な形態に照らしてみると、中庭に面した建物橧になる可 能性が高く、実際、大体において、共有壁を挟んで奐の建物梖同士 が際接する結果になっている。

(ii )一部分ではあるが、画地が売却された後に、画地の購入者同 士が、背割り線を挟んで小さな中庭の焦合体をつくる契約を結び、 土地利用の調整を図っている ${ }^{19)}$ (図3-3,e,h）。

（iii）一部において壁を挟んで建物と中庭が向かい合うが、その部 分に関しては予め、壁を建設した者が、未売却の篮地を所有する画

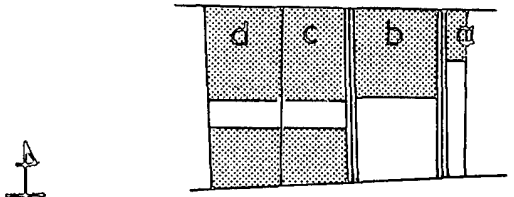

4

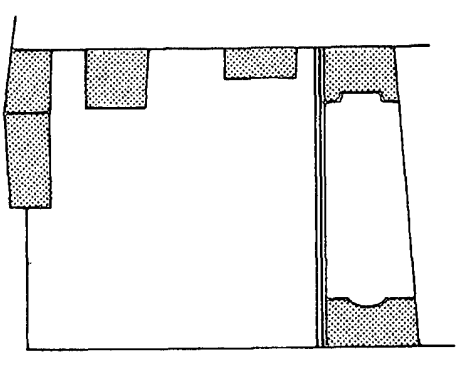

5

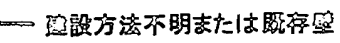

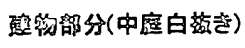
（缩尺 1/1250）

地分羡者に封して、一定の条件（画地分潑者自躬による際地の家屋

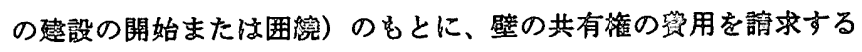

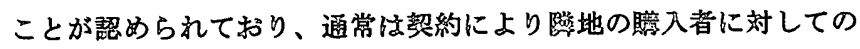
み諗められる费用請求の条件が僢和されている(图3-3, c/f間) ${ }^{20)}$ 。

(iv) 一連の背割り缐にかかる最初の画地（図3-3,b)の范却に際し ては、壳却地の上に壁を避設して土地を围うことが契約经件として 潩せられている21。その画地は與行きが比警的浅いため背割り缐に 接する部分が邆物と中庭になる可能性が高いが、その配愠が定まっ

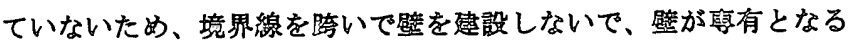
可能性を残したと考えられる。しかし、その画地の瞕入者と直後に

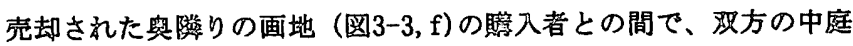
を向かい合わせに配置し、その共有壁を共同で䞹設することなどを 内容とする契約が交わされており、実際には壁は背割り湶を跨いで 建設されたとみられる221。

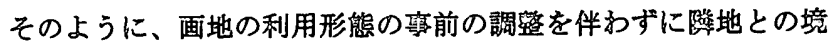
界線を跨いで壁が趋設された例においては、共有壁の中心缐の連獍 性を確保する必要性とともに、画地の形状に照らしてみて画地の利 用形態が陵地間で対忘する見込みがあり、さらに、画地等入者同士 による土地利用の調朢、あるいは画地分绫者による限定的な負担灭 任の引き受けなど共有壁の邀設を促す補足的な条件が䄈在した。

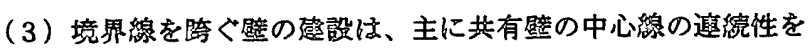
確保する必要がある状況で行われている。しかし、その必要珄を伴 わない、二つの画地の側面を画する共有聯が境界線を跨いで趮設さ れることもある。それらの例で住、共有壁となることを前提とした 境界線を跨ぐ譬の避設が受け容れられるのを促進したと考えられる 次の二つの条件が見出だされる。

（i 共有譬を续んで同斦の土地利用の部分が封応することを予望 させるに足る、画地の利用に関する詈前の契約合意もしくは画地の 
状況が存在する。一団の土地を間口に垂直な線で分割した画地分讓

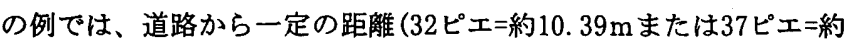
$12 \mathrm{~m}$ ）以上離れた画地の奥での建物の高さを制限する契約条件が存 在した ${ }^{23)}$ (図3-4。a は東隣りの土地に統合)。その高さの制限値 （20ピエ=約 $6.49 \mathrm{~m} ）$ は道路沿いの建物に対する法律上の高さ制限值 （最大軒高 54 ピエ $=17.54 \mathrm{~m}$ 、軒上屋根高 15 ピエ $=4.87 \mathrm{~m}$ ） ${ }^{24)}$ と比へ てかなり低く、画地奥の高さ制限区域内では共有壁の両側の土地利 用が対応する保証はないが、建物が建つ場合でも共有壁への物理的 負担の少ない低い建物である。逆に、道路沿いの部分では法規制い っぱいの高い建物が建つ可能性が大きいため、その部分の共有壁は、 建物の支持が可能となるよう堅固に、一定の厚さ ( 2 ピエ=約 $64.9 \mathrm{~cm}$ ) の基礎の上に建設することが義務付けられる場合もあった ${ }^{25)}$ 。

別の例では、大きな既存の邸宅地の分筆によって生み出された短 冊状の画地に、庭園をもつ邸宅形式の家屋が建設されることが予想 され、分筆後の新しい境界線の上に建設される共有壁の両側は主と して双方の邸宅の庭園となることが予想された ${ }^{26)}$ (図3-5）。

（ii）予め契約書において、建設される共有壁の高さが「 9 ピエ= $2.92 \mathrm{~m} 」 や 「$ 通常の囲壁の高さ」と指定されたり、あるいは「囲壁の 高さまで共有とする」として壁の共有の範囲が限定されている ${ }^{27)}$ 。 そこで言うところの 9 ピエや通常の囲壁の高さとは、慣習法の規定 を継承した民法の規定（663条）によって隣り合う敷地の一方の所有 者が他方に対して建設費等の分担を求めることが認められる囲壁

（囲絓壁）いわゆる強制囲壁の高さを意味すると考えられる。法律 に定められた強制囲壁の高さは、まずは個別の規則または慣行に基 づく高さであり、それが存在しない場合は $3.2 \mathrm{~m}=10$ ピエ(人口 5 万 人以上の都市）または2. $6 \mathrm{~m}=8$ ピエ（その他の都市）である。実際 に、パリでは10ピエまたは 9 ピエの高さの囲壁が建設されることが 多く、パリ慣習法は個別の取り決めがなければ囲壁の高さを10ピエ （但し、笠石の高さ 1 ピエを含む）とし、他の都市の慣習法も 9 ピ エもしくはそれに近い值を採用していた ${ }^{28)}$ 。

そうした囲壁は敷地の中庭等の空地部分を隔てる壁としてつくら れ、必ずしも建物の支持壁になるとは限らない。囲壁が共有壁であ れば、法律上、当事者の一方が自らの費用で壁をかさ上げし、さら に必要に応じて自分の土地に張り出させて壁を補強することも可能 であり、また、他方の当事者が費用を分担してかさ上げされた壁を 共有壁として利用することも可能である。従って、通常の高さの囲 壁を双方の画地に跨がる共有壁として建設し、必要に応じて壁のか さ上げや補強を行いながら建物を建設するという手順も考えられる。 それは当該の事例が示唆するところでもある。しかし、囲壁の厚さ についての法的基準はなく、パリでは通例では18プス（約 $48 \mathrm{~cm} ） の$ 厚さの囲壁がつくられた。それは建物の支持も可能な厚さであるが、 それを下回る厚さの囲壁もつくられ、逆に建物の支持などの必要に

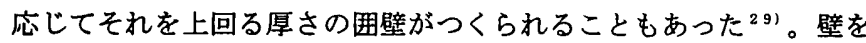
挟んで建物と中庭が向かい合う状況では、双方が必要とする共有壁 の厚さが必ずしも一致するとは限らない。従って、低い共有壁をつ くり必要に応じてかさ上げする方法は一見合理的であるが、実際上 は煩雑であり、特に双方の画地の利用形態が予想できない状況で第 三者が共有壁の建設の合意の仲介をする場合には、合意の実現に関 するリスクが大きくなる。そのため、それは共有壁を体系的につく りだす方法として一般化するには至らなかったと考えられる。

\section{4ー2．境界線を越えないで建設される塈}

方法 2 による共有壁の建設の例は、相前後して売却された道路沿 いの一連の画地の側面の境界において見られる(図3-3,b-f)。先発 の画地の購入者（例えば b ）が、売却契約の条件に従って、自分の 土地の上に隣地にかからないように壁を建設し、次に、後発の隣地 の購入者 (c ）が、その壁の共有権を取得すると同時に、反対側の 未売却の土地 (d) との間の境界を画する壁を同様にして自分の土 地の上に建設し、その共有権を未売却地の購入者が取得する ${ }^{301}$ 。そ れらの一連の画地よりもかなり早い時点で（約10年前）売却された 隣接する角地（図3-3,a)には共有壁の建設に関する契約条件がつけ られなかったが、購入者は未売却の隣地との間の壁を、問題のない ように自分の土地の上に建設し、隣地の購入者は後にその共有権を 取得した ${ }^{311}$ 。そのようにして画地の側面の境界の共有壁が順次建設 されていったが、そこには方法 1 によって共有壁が建設された状況 とは異なる次のような状況が見出だされる。

（i）方法 2 にっって建設されたそれらの壁は隣接する二つの画地 の側面の共有壁であり、その延長上にも他の共有壁は存在しない。 従って、壁の中心線の連続性を確保するという問題が生じない。

（ii）ほとんどの画地の売却の時点において、中庭集合体の形成に 関する契約合意のような隣り合う画地の利用形態の対応を保証する 事前の調整が存在しない。通常、家屋の建設によって画地の側面の いずれかの側には中庭が配置されるので、画地の利用形態が未定の 状況においては、側面の境界の壁を挟んで隣り合う家屋の建物と中 庭が隣接する可能性が存在する。

そのような状況において、まず、先発の画地の購入者は、自分の 土地の上に、建築計画に合わせて壁を建設することができる。他方、 後発の隣地の購入者は、必要に応じて、壁の応分の費用（通常、土 地と壁本体の費用の半分）を相手側に支払って壁を共有化すること ができ、また、壁を建設した側も契約に基づいて壁の共有化を相手 側に求めることができる。それらの権利が行使されなければ壁は専 有のままであり、壁が共有化された場合には、壁の中心線が画地の 新しい境界となる。従って、この共有壁の建設方法は、共有壁の中 心線の連続性を確保する必要がなく、そして隣り合う画地の利用形 態が予め調整されていない状況に適した、より自由度の高い共有壁 の形成の仕組みといえる。画地売却の時点で中庭集合体の形成に関 する契約合意が存在するにも関わらず、境界線を越えないで壁が建 設された例（図3-3,d)は、一連の隣り合う画地の分培過程で他の画 地の壁の建設方法に合わせた結果とみられるが、隣地との間の土地 利用の対応が予め保証されている状況でより自由度の高い共有壁の 建設方法がとられたのであるから、実際上の問題はない ${ }^{32)}$ 。

\section{5. 共有壁への䁔炉設備の埋設}

建物の壁はしばしば暖炉や煙道の埋設場所として利用された。䁔 炉や煙道は壁に埋設するほかに外付けする方法もあるが、埋設する ことによって利用可能な室内空間が広がるなどの利点があった ${ }^{33)}$ 。 19世紀後半（1874年）には、防災上の理由から、パリでは隣り合う 家屋の界壁もしくは共有壁に䁔炉や煙道を埋設することが知事令に よって禁止される ${ }^{34)}$ 。しかし、それ以前は、䁔炉の設置基準および 維持管理に関する規則は存在したが; 共有壁等への䁔炉や煙道の埋 


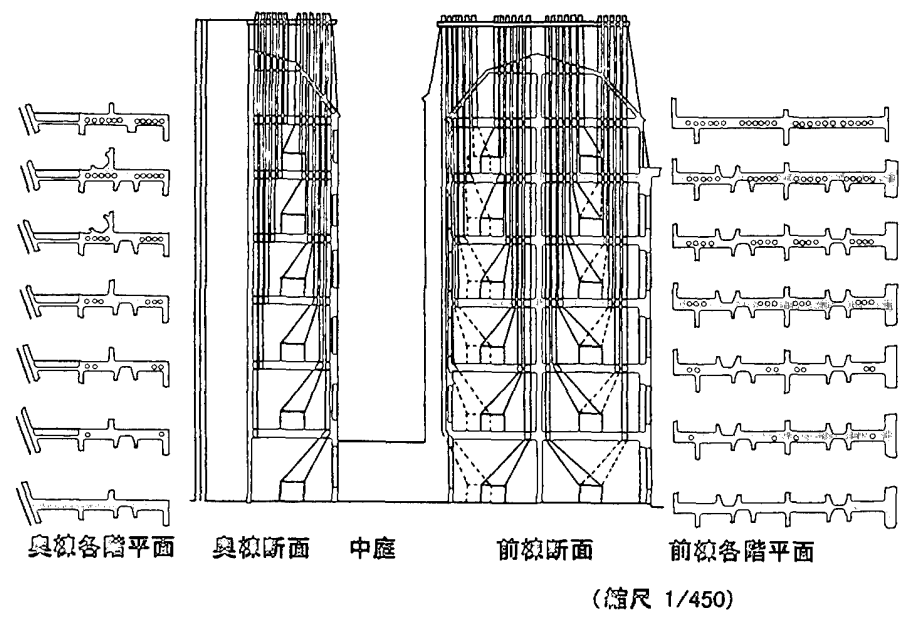

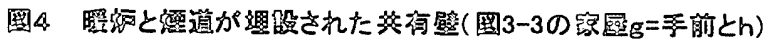

設は許容されており、実際にも行われていた ${ }^{35)}$ 。壁への暖炉等の埋

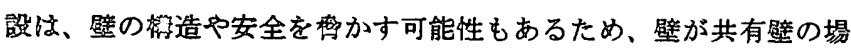
合泳、他方の共有箱者の同意を得て行われなければならなかった。

19世紀前半の画地分棓地区でも、家屋の菆設に伴う共有壁の建設

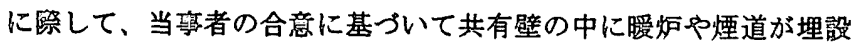
されることも少なくなかった。その場合、たいてい双方の家屋から 同锁をたはほほ同数（30本と28本、18本と17本、7本と6本等）の瞹 部と洷道が埋設され、共有壁の公平な利用が図られた（図 4) ${ }^{36)}$ 。 通常、瞬炉は壁の中心から手前に埋設され、煙道は壁の中心に埋設 されたが、煙道も中心から手前に埋設される場合もあった。

共有壁の路設に関する契約合意は、しばしば画地の売却の際に画

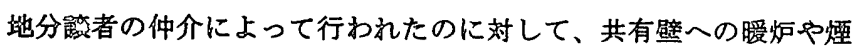
道の理設に関する契的合意は、家屋の建設の際に行われた。画地孛 却の段階では必ずしも遠築計画が定まっていないため、䁔炉や煙道 の配圆を決的ることは雚しかったためと考えられる。共有壁への瞬 沪队煙道の埋設が行われ、契約が交わされる状況は二つある。

(i)一つは、䑝り合う家屋が、同じ建築主によって、界壁の中に䁔 炉と洷道を埋設して速設され、後に、それらの暖炬と煙道の存在の 础翏と保全に閶する条件をつけて家屋が売却される場合である ${ }^{37}$ 。

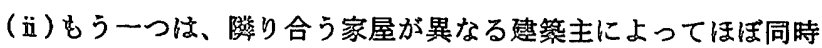
期に邀設される際に、双方の契約によって共有壁の中に䁔炬と煙道 が埋設され、その現状の保全の合意がなされる場合であり、それに はさらに梁約が京前に交わされる場合と尌後に交わされる場合があ

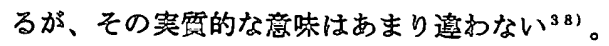

いずれにしても、共有壁への瞬炉や煙道の埋設が行われるために は、实際上は、共有壁が建設される段階で欢方の家屋の建築計画が ある徍度定まっている必要があった。

\section{6. 蚂らりに}

家屋の遈設が基本的に画地毎に個別に行われる市街地の形成の過 得において、䦐筑主の合意に基ついて安定した条件のもとで家屋の 篹合化の要淙である共有壁をつくりだすために、状況に応じて異な る共有譬の邆設方法が用いられた。

共有壁の䞳設方法は、同じ延長線上にある共有壁の中心線の遮䋉
珄を確保する必要性、および共有譬の両側の画地の利用形態の䞑応

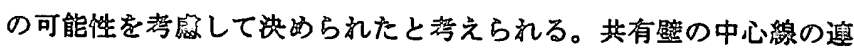
続珄を確保する必要があり、欢方の画地の利用形触が封応すること

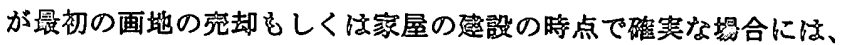

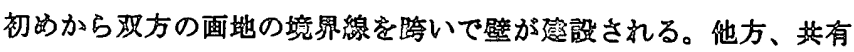

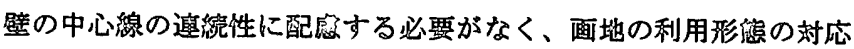

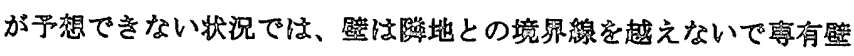
として燉設され、後に必要に応じて共有化される。しかし、画地の

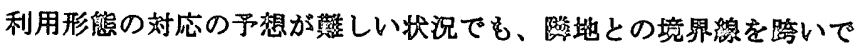

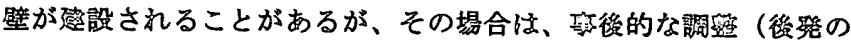

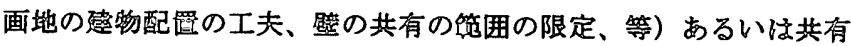
壁の铅用の分担のリスクを分散させる配慰（画地分羡者への限定的 な缶用請求の可能性、等) が行われる余地があった。通常の囲照の 高さ程度の低い共有壁を裂設し、後に必要に応じてかさ上げする方

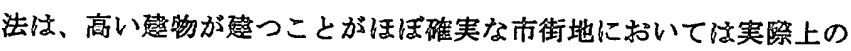

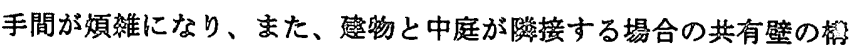
造についての当旁者の利容が必ずしも十分に調臨されないなどの問 題を伴うので、必ずしも一般化しなかった。

そうした共有壁の形成過独には、共有壁を歌嗢的につくろうとす る意图と、当亳者の利害を調空しようとする意图が反映されている。

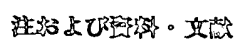

1) 中庭型家屋の犦成原理については既往の論文がある。鈴杢隆、「間の結合

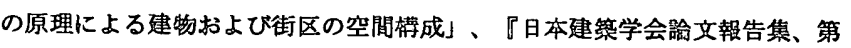
342 号、昭和59年8月、pp. 83-93。

2) HAROUELによえば、古代ローマの12埕版法は、火炎の延焼防止や通路の確 保などのために、踔地との境界缐からの建物の後退（2.5ピエ=約 $75 \mathrm{cn}$ 以上）

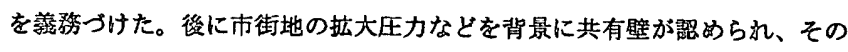

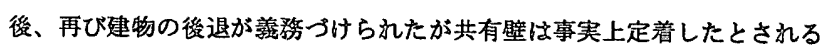

(J.L. HAROUEL, "Histoire de l' urbanisme", 1981, pp. 21-23)。 3) "Plan d'occupation des sols de la Ville de Paris", 1989。

4)例えば、リヨンの都市計画は、都心の地城などに执いて、道路から一定の

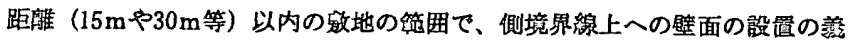
努付けを可能とする ("Plan d'occupation des sols de Lyon", 1990)。 5) 共有壁を含む建築法制に関しては、例えげLIET-VEAUXの研究がある。LIET -VEAUX, "Le droit de la construction", 1987。

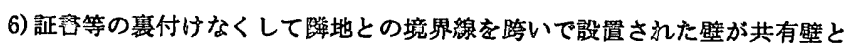

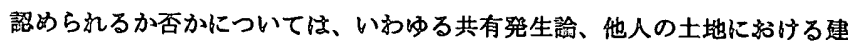
設諭、権利侵害諭、共有目的詥などの異なる解勍が存在する (LIET-VEAUX, 前揭苦，pp. 61-65）。

7)路地の壁を强用を支払って共有壁とする場合、現行の民法の規定では、そ の時点での壁の状熊に基づいて塈の価格が評価される。

8) 共有壁の共有梅者は、反効僛の壁面から54m（2プス）手前をで梁や根太 を壁に埋設することができ、反封側の共有篗者は同じ简所に梁や瞹炉を埋設 しょうとする場合は、既存の㳅などを壁の中心線をで削ることができる。 9）「負担の賠㜚」という民法の当初の規定は具体性を欠くため、後の法改正

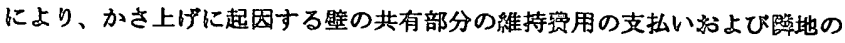
所有者にとって必要となるあらゅる支出の返过と規定され直した（1960年5 月17日の法律第464号)。 
10）共有䇒の建設等に関する条件は、契約書の義務負担条項もしくは様々な 名称（共有壁、地役、所見、共有権、地役、共有権および地役、地役の開陳、 共有壁に関する協定の喚起、等）を冠せられた特記事項の中に記された。 11)鈴木隆、「住宅建物建築主の特性と建築財政の構造」，『日本建筑学会計 画系論文報告集』、第392号、昭和63年10月、pp. 93-113。 12) 1838年5月5日の共有権に関する契約（LOUVANCOUR）。 13）鈴木隆，「十九世紀前半のパリの市街地における中庭の整備と中庭拹定」, 『第17回日本都市計画学会学術研究発表会論文集』，昭和57年度, pp. 451-456。 14）1845年11月14日のデブフ夫妻からポテル夫妻とシャボへの土地の売却お よびメイエとブッシェのための委託申告の証書（DORIVAL）；1847年2月 23, 24, 26 日のポテル夫妻とシャボーの土地の売却の証書(POTIER）；1847年4月13日 のポテル夫妻とシャボへの土地の売却およびドリア夫妻のための委託申告 (POTIER)。例えば、最初の画地（図3-1, a) の売却契約によれば、「売却 地と売主の残りの土地との間の壁は、（双方の土地にかかるよう）共有地上 に建設されなければならない。それにより、(隣地の所有者は) 壁の建郡者 に対して壁本体の価格の半分を支払うのみで、壁の共有権を取得できる」。 15) 1837年2月21, 22 日のベノワ伯爵夫人およびデバン・ウェルヌイユ夫人か らエドワンとクルタンへの土地の売却の証書（CLAIRET）；1837年2月23，24， 28日のバスティアンへの土地の売却の証書（CADET DE CHAMBINE）；1837年3 月18,20日のショソンへの土地の売却の証書（NORES）；1839年3月30日のル ル夫妻からピエレ夫人への家屋の孛却の証書（BOUDIN DE VESVRES）。例え ば、最初の画地（図3-2, a）の売却契約によれぱ、「（買主は、隣地にかか るよう）共有地上て建設を行い、塈の共有権の費用を隣地の購入者にしか請 求できない。(・・) 瞵地の購入者が先に建設を行った場合は、隣地の購 入者に壁の共有権の費用を返還しなければならない」。

16) 1837 年4月14, 16 日のベノワ伯爵夫人からルプリウールへの土地の売却の 証费 (DREUX)。

17) 1838年10月17, 18日のショソンからルル夫妻への家屋の艺却証書(NORES)。 18）画地（図3-3, d）の購入者には次の義務が課せられた。「購入地の奥のサ ン・ジョルジュ社（売主）の土地との間に、双方の土地に半分ずつかかるよ うに、買主の費用で壁を設置すること。但し、瞵地の購入者に対して、もし くはサン・ジョルジュ社が家屋の建設を行う場合には同社に対して、壁の建 設費用の半分を請求できる。」（1835年8月14日のノタンからバスティアン 一の土地の売却の証書、JAZERAND)。他の共有壁も同様にして建設された （1837年6月13日のルマリエ夫妻からアルノへの家屋の売却の証書、BOUDIN DE VESVRES；1835年6月6日のサン・ジョルジュ社からゲリマンへの土地の克 却の証書、BATARDY；1835年4月21,22日のドーヌ、ロワニョン、サンシィエ がらバシュロへの土地の売却の証曺、BONNAIRE) 。

19）1837年6月13日のルマリエ夫妻からアルノへの家屋の売却の証書（前出）。 20) 1835年4月 21,22 日のドーヌ、ロワニョン、サンシィエからバシュロへの 土地の売却の証書（前出）。

21) 1835年4月 2 日のサン・ジョルジュ社からリオネへの土地の売却の証書 (FOUCHER)。

22) 1835年4月23日のバシュロとリオネの間の私署証書。1837年 2 月 4 日のバシ ュロからブレへの家屋の売却の証書（JAMIN）。

23) 1828年6月14日のラブール夫人からセボへの土地の売却およびポンポン夫 妻への土地の売却の証書 (CRISTY)。1830年6月30日のラフール夫人からル フュエル夫妻への土地の売却およびデジョルジュへの土地の売却の証書 (COTELLE) 。

24) 1784年8月25日の「パリの家屋の高さに関する公開状」。
25) 1828年6月14日のラブール夫人からセボへの土地の売却の証書（前出）。 26)1826年5月11日のコンスタンタンからロディエールへの土地の売却の証書 (MAINE-GLATIGNY) 。

27) 1828 年6月14日のラプール夫人からセボへの土地の売却およびポンポン夫 妻への土地の売却の証書（前出）。1826年5月11日のコンスタンタンからロ ディエールへの土地の売却の証書（前出）。

28)パリ以外の都市の慣習法における囲壁の高さは次の通り。7ピエ : アミ アン、オルレアン、ドゥルダン。7.5ピエ : ナント。8ピエ : ムラン（庭園部 分）、セダン、モー。 9 ピエ：カレ、ムラン（中庭部部分）、エタンプ（庭 園部分)、ラン、ランス (郊外域)。12ピエ：エタンプ（中庭部分）、ラン ス (市域)。(DESGODETS, "Les lois des bâtiments, suivant la Coutume de Paris", Paris, 1787, pp339-342)。

29) DESGODETS, 前出, p. 352 。

30) 画地（図3-3, b）の購入者は次の義務を課せられた。「范主が所有する隣 地に面して、自分の土地の上に自らの費用で壁を建設すること。但し、瞵地 の購入者に対して、䇒の共有権の取得を要求することができる。」（1835年 4月2日のサン・ジョルジュ社からリオネへの土地の売却の証書、前出）。 31)1825年5月19, 25 日のラペリエールからトマへの土地の兌却の証書（MAINE -GLATIGNY）。瞵地（図3-3,f）の売却契約書には、角地（図3-3, a）の壁の 共有権が売却対象に含まれないことが明記された（1835年4月21, 22 日のドー ヌ、ロワニョン、サンシィエからバシュロへの土地の売却の証書、前出）。 32) 1835年8月14日のノタンからバスティアンへの土地の売却の証書（前出）。 33）17世紀の建筑家ル・ミュエは設計手引書の中で、「壁が専有であれば居 間の暖炬の煙道は壁に埋設する方が良いが、壁が尃有でなければ外付けとす る」として、制約がなければ煙道を壁に埋設することを推奖する（LE MUET, "Manière de bien bastir pour toutes sortes de personnes", 1623, p. 3)。 34) 1874年8月8日の「パリの家屋の内部における哣道の建設に関する知事 令」。但し、割栗石造 $(40 \mathrm{~cm}$ 厚) およびレンガ造 $(37 \mathrm{~cm}$ 厚) の仕切り壁への 所定の構造をもつ煙道の埋設は認められた。

35) 1672年1月26日の「暖灯の建設に関するシャトレのオルドナンス」は、䁔炬 の火床下および煙道の各階取り付き部分への框組の設置、および石亮造(2.5 プス厚）の煙道仕切り壁の設置などの構造基淮、ならびに、家主および貨借 人の暖炬の清掃の義務と出火の際の賁任（爵金100リーヴル）を定めた。 36)建設請負業ルマリエ夫妻は、共有壁の中にそれぞれ17本（4本は暖炬末 設）および18本（1本は壁外付け）の䁔炉用煙道をもつ 2 軒の家屋を建設し、 煙道の存在等を確認する契約条件をつけて克却した（図4) (1836年11月19日 のコリエへの家屋の売却の証書 ; 1837年6月13日のアルノへの家屋の売却の 証書、BOUDIN DE VESVRES) 。

37)ルマリエ夫妻は、前注36の家屋のほかに、共有壁の中にそれぞれ 7 本お よび 6 本の䁔炬用煙道をもつ 2 軒の家屋も建設・壳却している（1839年4月9 日のルマリエからサラールへの家屋の売却の証费、LOUVANCOUR）。 38) 隣接する家屋の異なる建築主が、共有壁に暖炉等を埋設し、その保全の ために交わした契約例：「大壁の中に設置されたションンのための28の暖炉 とブシャのための 30 暖炬、およびその補強部分を現状に保全するものとす る」（1837年6月10日の私署証書；1839年1月19日のプシャ夫妻からクルへの 家屋の売却の証書、LOUVANCOUR）。契約が家屋の建設に先だって結ばれた例 では：「(二つの画地の間の）壁の中に䁔炉を設置することができるものと し、その数はそれぞれの家屋について同数とする」（1846年4月10日のプレ とリェーヴルの間の相臨势定、THION DE LA CHAUME；1846年4月16日のノエ ルからエティエンヌへの土地の売却の証書、THION DE LA CHAUME)。

（2000年 4 月 7 日原稿受理，2000年 7 月 13 日採用決定） 